Jpn. J. Oral Biol., 23 : 691-697, 1981.

\title{
イイジマウミへビ歯牙の退化現象
}

\author{
石山巳喜夫 小川辰之 \\ 日本歯科大学新潟歯学部口腔解剖学教室第 2 講座 (主任 : 小川辰之教授)
}

[受付 : 昭和56年 9 月 4 日]

\section{Devolutive dentitions of the sea snake, Emydocephalus ijimae}

\author{
Mikio Ishiyama and Tatsuyuki Ogawa \\ Department of Oral Anatomy, Nippon Dental University, 1-8, \\ Hamaura-cho, Niigata 951 \\ (Chief : Prof. Tatsuyuki Ogawa)
}

[Accepted for publication September 4, 1981]

Key words : sea snake/dentition/devolution/tooth germ/dental lamina

\begin{abstract}
The sea snake, E. ijimae, has no functional teeth other than maxillary fangs and pterygoid teeth in the jaws as has been observed in the present species by Voris (1966). Histological examination by light microscopy reveals that the dentary and palatine dental laminae exist close to the dentary and palatine bones respectively and the maxillary dental laminae is separated backward of the maxilla in the adult specimen. On the other hand, the fetus, nearly ready for birth, has tooth germs which are situated in superficial portion of the oral mucosa and also near the dentary bones. Because of these histological structures, the dentition of both specimens are apparently vestigial, and by taking the com. parative anatomy and/or dietary habit into consideration, the present species of degenerated dentition may have originated from ancestral toothed species.
\end{abstract}

\section{緒言 \\ イイジマウミヘビ (Emydocephalus ijimae,} Fig. 1)はへビ亜目 (Ophidia), ウミへビ科(Hydrophiidae) に属し1,2), 琉球列島および 台湾周辺の 海域に分布する毒蛇である。Emydocephalus 属に は本種の他にもう一種, Emydocephalus annulatus が存在し，オーストラリア北部海域を中心とする 南西太平洋に分布することが知られている ${ }^{3)}$ 。

一般に，へビ類は上顎においては，上顎骨，口 蓋骨および翼状骨に，下顎には歯骨に，それぞれ 歯牙が植立する ${ }^{1,4,5)}$ (Fig. 2)。しかし, 前述の 2 種においては，これらの歯牙のうち，口蓋骨歯と 歯骨歯および他のウミへビ類には存在する毒牙後

新潟市浜浦町 1-8（广 951）
方の小歯が欠如すると報告されている ${ }^{6)}$ 。

この現象を比較解剖学的に考察すると, 現在こ れらの部位で欠如する歯牙も, 過去においては存 在し,さらには機能していたものと推測される。 また, ウミへビ類の起源はコブラ類の一部が進化 の過程で, 二次的に海洋へと住み場を移動した時 に始まったと考えられている。したがって, 爬虫 類の進化史上よりみて, その分化の歴史は比較的 浅いものと思われる。

以上の論拠によれば, Emydocephalus 属の 2 種 が歯牙を品失した時期も, それ程遠い過去とは考 えられず，現生種においても，過去における歯牙 の存在を示唆する形象が, 残存している可能性が ある。著者らは, イイジマウミへビの成体と胎仔 を用い, 頭部を組織学的に検索して, 前述の仮説 


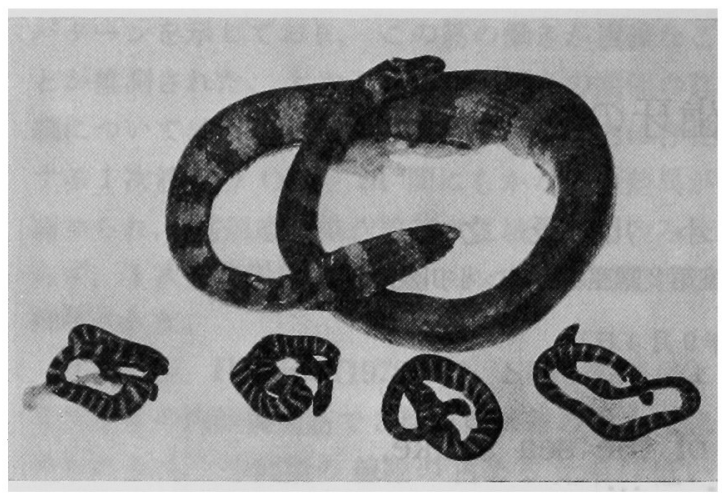

Fig. 1 General appearance of the adult sea snake (total length $95.5 \mathrm{~cm}$ ) and conceived four fetuses.

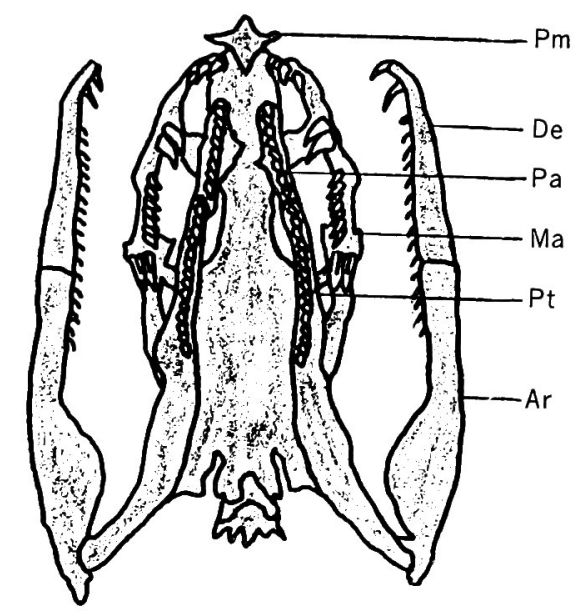

Fig. 2 Ventral view of the skull of Python molurus (semi-schematic illustration). Ar, articular; De, dentary; Ma, maxilla; $\mathrm{Pa}$, palatine; $\mathrm{Pm}$, premaxilla ; $\mathrm{Pt}$, pterygoid. (redrawned from $\mathrm{PE}$ YER, 1968)

の立証を試みた。

\section{材料および方法}

材料のイイジマウミへビは, 成体 4 尾（全長 $95.5 \sim 54 \mathrm{~cm}$ ), 胎仔 4 尾（全長 $28 \mathrm{~cm}$ 前後）の計 8 尾で, いずれも沖繩県瀬底島において採集 (1979 年11月）されたものである。なお，胎仔 4 尾は成 体 $(95.5 \mathrm{~cm})$ の孕していたもので, 出産直前と推 定されるほど発育段階の進んだものである (Fig. 1 )。

採集後, 成体の 1 尾をのぞき, Bouin 固定し,
その後10\%蟻酸・ホルマリン液で脱灰した。つい で，上，下枵を正中断により二分し，通法に従 いパラフィン包埋後, 厚さ $10 \mu \mathrm{m}$ で前頭断と水平 断の連続切片を作製，これに H-E，Azan，van Giesonの各染色を行ない鏡検した。

また，残りの成体 1 尾を10\%中性ホルマリン固 定後, 軟X線撮影装置 (SOFRON, SRO-M 50) で頭部撮影，つぎに骨周辺の軟組織を除去し，各 骨を露出して剖検した。

\section{結 果}

1. 解剖学的所見

本種の成体 4 尾は共通して，口蓋骨と上顎骨の 毒牙後方部位，また下頡では歯骨，以上の 3 部位 で歯牙が欠如する (Fig. 3，4，5)。さらに毒牙お よび翼状骨歯は他のウミへビ類に比較して, 非常 に矮小である。また，胎仔 4 尾の歯牙の形態にも 同様の現象が認められる。

2. 組織学的所見

1）成体 3 尾には共に，同様な残存歯堤が認め られる。すなわち, 口蓋骨の唇側と歯骨の舌側に 接して形成されている (Fig. 6，7)。また，上顎 骨の毒牙を形成する歯堤では，毒牙の形成に必要 な位置より,さらに後方に長く伸展している(Fig. $8)$ 。この伸展部は 前述の 欠如小歯に 対応する部 位であり，この部分が歯牙形成能を全う出来なか った残存歯堤として，存在しているものと思われ る。さらに, 以上の部位を水平断で観察すると, 歯堤の長さは近接する骨の長径にほぼ等しく， か つ骨の長軸に平行した，帯状の層として認められ る。

これら歯堤はいずれも深い陥入を示しておうう， 形態的に一部欠損, 断裂および変形等は認められ ない。したがって，退化痕跡的な形態を示すので はなく，通常の歯牙形成の未分化な状態で停止し ている像を示す。事実, これら歯堤の自由縁細胞 群は活動的な状態を示し，さらに結合組織側には 間葉系細胞の集合が認められる(Fig. 9)。この形 象は，通常の歯牙発生時の蕾状期に相当し，本歯 堤にはいまだに歯牙形成能が残存しているように 見受けられるが，それ以上の分化を示さず歯牙形 成には至らない。なお，本現象は歯骨の隣接歯堤 


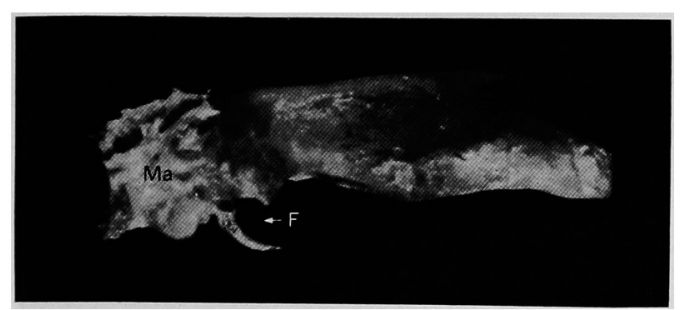

Fig. 3 Lateral view of right maxilla (Ma) of the female adult (total length $73 \mathrm{~cm}$ ). Note that the maxillary dentition is only the fang $(F)$.

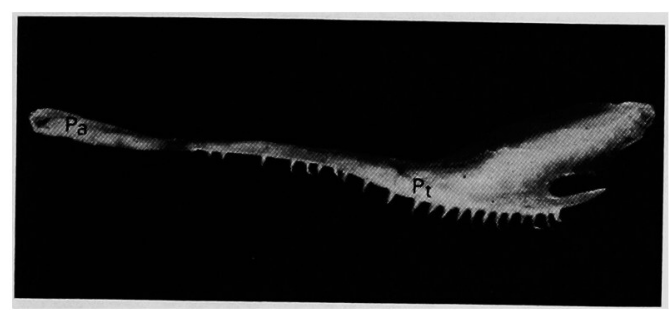

Fig. 4 Lateral view of right palatine $(\mathrm{Pa})$ and pterygoid $(\mathrm{Pt})$ of the female adult (total length $73 \mathrm{~cm}$ ). The palatine lacks dentition.

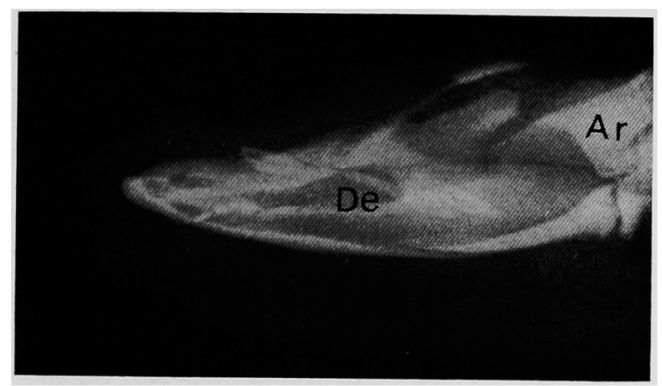

Fig. $5 \mathrm{X}$ ray photograph of right mandible of the female adult (total length $73 \mathrm{~cm}$ ). The dentary lacks dentition. De, dentary; Ar, articular.

において，最も顕著である。

2）胎仔 4 尾について検索の結果，成体と同様 な形態で歯堤の形成がなされている。しかし，成 体と著しく異なる点は，部分的ではあるが，歯胚 列の形成にまで分化が進んでいることである。す なわち, 歯骨舌側と咽頭底とに, その存在が認め られる(Fig. 10〜16)。

これらの歯胚列の発現性は, 非常に不安定であ って，その形成部位が個体ごとに異なり一定して
いない。試料の 2 個体 (A 組) においては，本来 の形成位置である歯骨の舌側に存在するが，他の 2 個体（B組）においては，本来の形成位置から 遠く離れた，咽頭底の粘膜中に形成像が観察され る。A組とB組とを比較すると, A 組では歯胚列 の形成が 1 列のみであるが(Fig. 11，14)， B 組で は多数列の形成が認められる(Fig. 12，13)。さら に, 今回の試料には歯胚列の形成が, 両側性のも のは 1 個体もなく，左右いずれかの一方に偏在し ている。

また，以上の歯胚列にあっては，何れも植立と は無関係に，上皮直下の固有層浅層中に存在して いる(Fig. 14)。なお， 本歯胚中の高成熟のもの は, 萌出活動への進展を示す以前に, 退化萎縮し てしまう(Fig. 15)。

\section{考察}

比較解剖学的, あるいは系統発生学的な考察に よると，現生種に欠如する歯牙が，その祖先形に は存在していたと推測される動物に，鳥類，ヒゲ クジラ類, カメ類, およびヒキガエル類などがあ げられる。以上の種類は，いずれも進化の過程 で, 種々の要因により歯牙を失う結果になったも のと推論されている。

なお, 前述のうちヒゲクジラ類には, 胎児期に おいて，硬組織の形成まで達した歯胚の存在が知 られている7”。さらに，その歯胚のうちで遠心位 のものは，化石鯨類にみられるのと同様な，複咬 頭性を示すといわれており，遠い過去での歯牙形 態を示唆するものと推察されている。以上の現象 はいずれもヒゲクジラ類の進化過程を示すもので あり, Haeckel の「反復の法則」の一例とされて (る8)。

このように，進化の過程で消失した歯牙が，そ の個体発生の過程に出現する例は，このヒゲクジ ラ類の他にハクジラ類のッチクジラ (Berardius bairdii）の上顎が知られており，成体には上顎 歯が存在しないが，胎児の中には硬組織の形成ま で進んだ歯胚を有するものがあると報告されてい る ${ }^{9)}$ 。

以上はいずれも鯨類における現象であり，哺乳 類をのぞいた脊椎動物中には，現在に至るまで同 


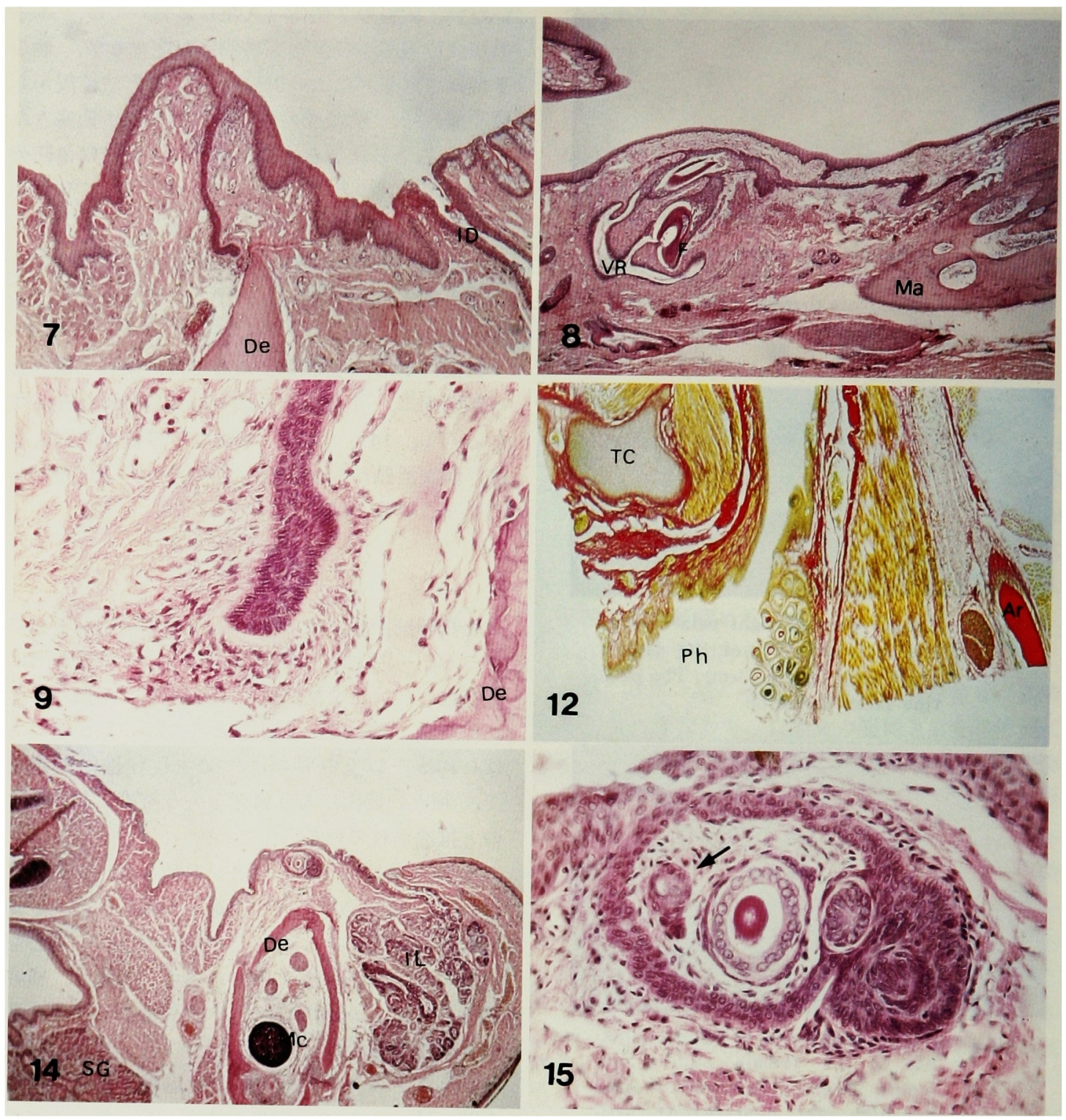

Fig. 7 Frontal section through the mandible of the female adult (total length $95.5 \mathrm{~cm}$ ). Note dental lamina near the dentary (De). ID, duct of infralabial gland. H-E stain. $\times 40$.

Fig. 8 Horizontal section through upper jaw of male adult (total length $59 \mathrm{~cm}$ ). The dental lamina of fang extend posteriorly in far distance. $\mathrm{F}$, fang; $\mathrm{Ma}$, maxilla; VR, venom reservoir. H-E stain. $\times 20$.

Fig. 9 Enlarged view of dental lamina existing near the dentary (De). Note the activated free margin cells of dental lamina and assemble of mesenchymal cells arround the free margin. female adult (total length $95.5 \mathrm{~cm}$ ). H-E stain. $\times 200$.

Fig. 12 Tooth families in pharyngeal fundus of the fetus (B1). Ar, articular; Ph, pharynx; TC, tracheal cartilage. VANGIESON stain. $\times 30$.

Fig. 14 Frontal section through the mandibule of the fetus (A 2). Note the tooth family situated in just under the epithelium. De, dentary; IL, infralabial gland; MC, Meckel's cartilage. H-E stain. $\times 20$

Fig. 15 Detail of Fig. 14 showing tooth family. The degenerative appearance can be seen in the most maturated tooth germ (arrow). H-E stain. $\times 200$. 


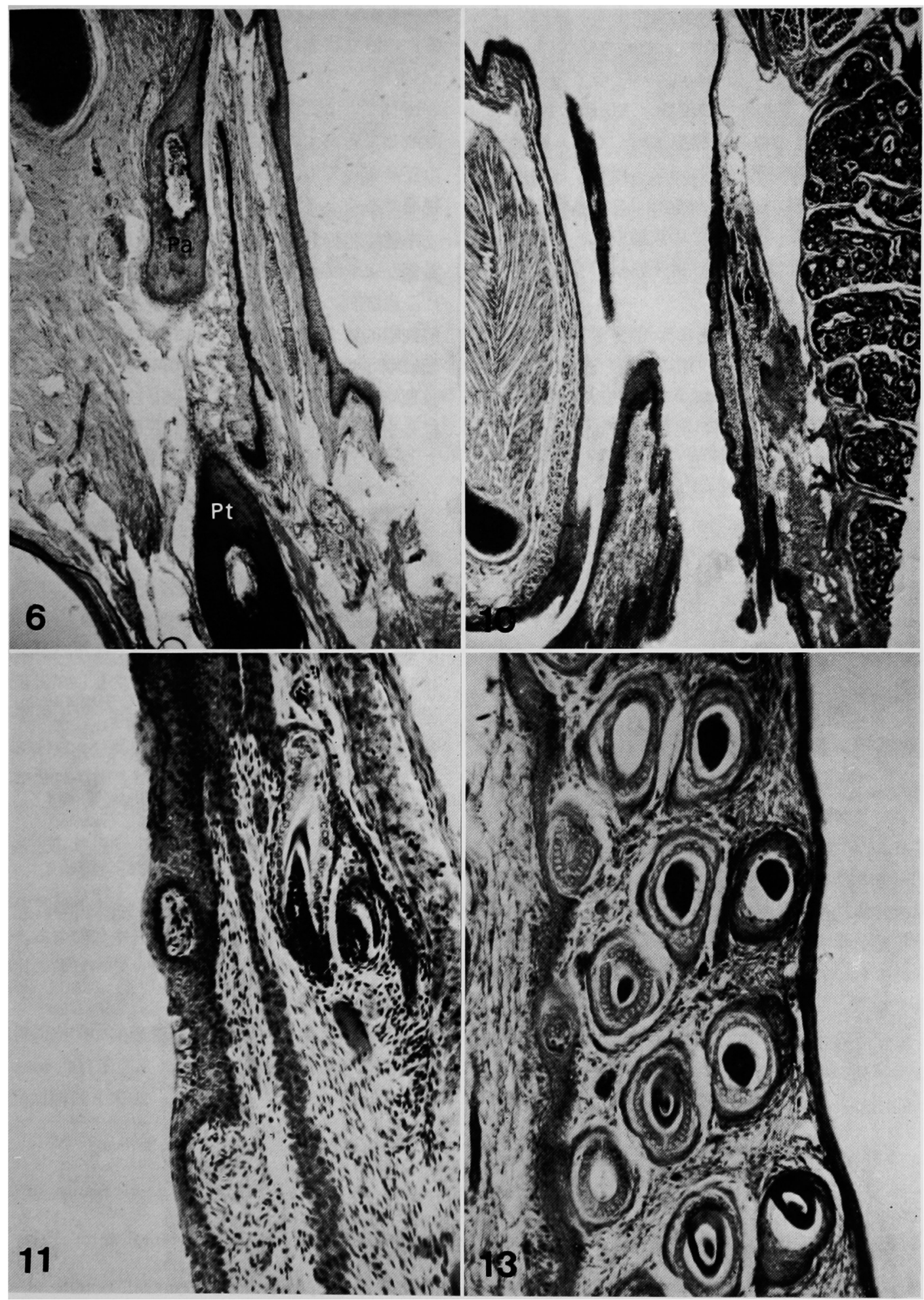


様な報告例は見あたらない。その中で，宮内 ${ }^{10)}$ は ヒキガエル (Bufo vulgaris formosus) の上, 下 顎执よびッチガェル(Rana rugosa) の下顎を発生 初期から変態に至るまでの期間, 組織学的に検索 した結果，歯牙の原基は出現せず，これらの歯牙 を失った時期は系統発生学的に，極めて遠い過去 であろうと記載している。また，これと軌を一に する研究として, 小川 ${ }^{111}$ は10数種のカメ類の上, 下顎を組織学的に検索し，歯牙原基の存在を否定 する報告をしている。

今回のイイジマウミへビには部分無歯に対応す る位置に，胎仔期に歯胚の形成がみられる。この 現象は前述のヒゲクジラ類，およびッチクジラの 例と共通性を有し，相同の現象と考えられる。

また，歯牙原基の胎仔より成体までの変化につ いて考察すると，胎仔期に歯堤および歯胚の形成 があり，このうち歯胚のみは胎仔期中，あるいは 出産後間もなく破壊吸収されてしまい，成体にあ っては 1 個の遺残も認め得ない。これに対して, 歯堤は, 成体にあっても永く残存する運命を有し ている。さらに, 成体において残存歯堤の自由縁 細胞の活性化を示す形象が認められた。なかんず く, この傾向は下顎の歯骨の隣接歯堤において最 も顕著であり，いまだに歯牙形成能を保持してい るように思わしめる。

しかしながら，前述の歯堤や歯胚は，退化の進 展によって, 遠い将来には発現不能となる可能性 があると推測される。さらに，成体の毒牙および 翼状骨歯は非常に矮小化しており，明らかに退化 の兆候を示寸形象変化と考えられる。したがって, 本種においては完全無歯への方向に進行中とも推 察される。

また，胎仔の歯骨舌側および咽頭底に形成され る歯胚列の発現位置が，かなり不安定であること は前述した。これと関連したものに，松浦 ${ }^{12)} の マ$
ッコウクジラ (Physeter catodon) の上狉歯（痕跡 歯）の植立状態に関する報告がある。すなわち， 「不規則で， かつ本来の歯槽の位置を外れている」 と述べている。本例とイイジマウミへビの例とを 対照して考察すると，退化過程にある歯牙は程度 の差はあっても，形成位置の不規則性が共通の一 現象であると示唆される。

本種の胎仔 B 組で，本来の歯牙形成部位（歯骨 舌側）よりかなりかけ離れた位置である咽頭底 に，歯胚列の形成が認められた。この現象を比較 解剖学的に考察すると, 魚類においては多くの種 類に咽頭歯の存在が認められている。しかし, 爬 虫類ではこの形象異変に関して, 古生物学的, 系 統発生学的, 比較解剖学的にも説明がつけがたく, このような位置に形成される意義については，現 在のところ不明である。

また, Voris ${ }^{6}$ は本種と E. annulatus の食性に 関して, 魚卵の単一捕食というウミへビ類の中で は特異な食性であることを報告している。また， Mcdowell ${ }^{13)}$ は分類学上, 本種と近縁種とされて いる, Aipysurus eydouxi も単一ではないが，し ばしば魚卵を捕食する習性を有し，そして歯牙が 全て矮小化していると記載している。以上の事項 について考察すると，魚卵の捕食という食性は， ウミへビ類の歯牙を退化の方向へと向かわせた, 重要な要因の一つであると推察される。

\section{結論}

1. イイジマウミへビの口蓋骨歯，上堮骨の毒 牙後方小歯，および下顎の歯骨歯は欠如する。ま た，毒牙および翼状骨歯は他のウミへビ類に比較 して, 非常に矮小である。

2. 成体において, 上記の歯牙欠如部位に対応 して, 歯堤の形成が認められ，永く残存する。

3. 成長の進んだ胎仔にも，成体と同様に歯堤

Fig. 6 Horizontal section through the palate of the female adult (total length $95.5 \mathrm{~cm}$ ). Note dental lamina near the palatine $(\mathrm{Pa})$. Pt, pterygoid. $\mathrm{H}-\mathrm{E}$ stain. $\times 30$.

Fig. 10 Horizontal section through the mandible of the fetus (A1). Note the tooth family in a single row. IL, infralabial gland. H.E stain. $\times 30$.

Fig. 11 Detail of Fig. 10. Note the dentine formation in the most maturated dental germ. H-E stain. $\times 150$.

Fig. 13 Enlarged view of tooth families showing normal development in pharyngeal fundus of the fetus (B2). Azan stain. $\times 150$. 
の形成があり，さらに部分的ではあるが，歯胚列 の形成が認められる。

4. 上記より，本種の部分無歯は過去における 存在歯牙の, 二次的退化によるものと推察した。

5. 本種の, 魚卵の単一捕食という特殊な食性 は，歯牙退化の重要な一要因と考えられる。

謝辞：稿を終るにあたり，著者らが日頃から歯の比較 解剖学について御指導いただいている, 日本歯科大学画 学部, 長浜晋教授に感謝の意を表します。また, 貴重な
実験材料の御提供をいただいた，新潟大学理学部，本間 義治助教授，㧍よびウミへビ類に関する資料を择借した， 日本歯科大学新潟歯学部, 夏野徽也講師, 御二人の御協 力に対し感謝の意を表します。そして，同室の吉江紀夫 講師には本研究に対し種々の御助言をいただきました, 本紙面を择借して感謝の意を表します。

な㧍, 本論文の要旨は昭和 55 年度㐘科基整医学会総会 (松戸), 抢上び昭和55年度日本歯科大学歯学会大会（東 京）にて発表した。

抄録 : イイジマウミへビの口蓋骨歯，毒牙後方の上蕦骨小歯，および下頡の歯骨歯は欠如する。しかし， 比較解剖学的考察によれば，これらの歯牙は過去において存在していたことが推測され，さらに現生種にお いても，退化過程にある歯牙原基の残存が示唆される。本種の成体と胎仔の頭部を組織学的に検索した結果, 成体では前述の各骨に隣接して, 歯堤の形成が認められ, 胎仔においては, 歯堤の形成に加え, 歯骨の舌側 および咽頭底に歯肧列が観察された。なお，これら歯胚列はいずれも，上皮直下の固有層浅層中に形成され ており，植立および萌出には至らない痕跡的な形象である。以上のように，歯牙の久如部位に相当して，歯 牙原基の形成が行なわれるところから，本種の部分無歯は過去における存在歯牙の，二次的退化によるもの と推察した。

\section{文献}

1) 牧茂市郎: 日本蛇類図説. 復刻版, 第一書房, 東京, 1978 .

2) 中村健児，上野俊一：原色日本両生爬虫類図鑑， 133-188, 保育社, 東京, 1963.

3) Cogger, H. G.: Sea snakes of Australia and New Guinea [The biology of sea snakes, Danson, W. A.] University Park Press, London, 1975.

4）長浜 晋：日本産無毒蛇頭蓋骨（附某ノ下䫟可 動装置) 站歯牙二就キテノ/解剖学的研究, 解剖 誌, $16: 112-141,1940$.

5) Edmund, A. G.: Dentition [Biology of the Reptilia. Vol. 1, Gans, C.] 177-200, Academic Press, London, 1975.

6) VORIs, H. K.: Fish eggs as the apparant sole food item for a genus of sea snake,
Emydocephalus (Krefft), Ecology, 47: 152154, 1966.

7) SLIJPER, E. J. ; 細川 宏, 神谷敏郎訳 : 鯨, 257-260, 東京大学出版会, 東京, 1965.

8）駒井 卓: 遺伝学に基づく生物の進化，371-377, 培風館, 東京, 1963 .

9）桐野忠大, 橋本 嚴: 槌鯨の上額歯. 口腔病学 会誌, $19: 217,1952$.

10）宮内常三：ヒキガエルに於ける歯牙原基の有無 に就て. 口腔病学会誌, $\mathbf{1 1}: 363,1937$.

11）小川辰之： カメの歯についての解剖学的研究. 歯学, 58(4) : 471-512, 1970.

12）松浦義雄：抹香鯨の歯の出現状態. 植物及び動 物, $8: 86-88,1940$.

13) MCDowell, S. B.: The genera of seasnakes of the Hydrophis group. Trans. Zool. Soc. Lond. 32 : 189-247, 1972. 